Ана Римар

Универзитет у Новим Садзе

Филозофски факултет

Оддзелєнє за русинистику

ana.rimar@yahoo.com
UDK 821.161.2(497.11).09 Kovač M UDK 821.161.2(497.11).09 Stefanik V.

\title{
УПЛЇВ ВАСИЛЯ СТЕФАНИКА НА ЛИТЕРАТУРНЕ ДЇЛО МИХАЙЛА КОВАЧА*
}

Абстракт: На литературне дїло Михайла Ковача значно уплївовали класики українскей литератури. Ковач читал дїла велїх авторох, гоч нє вше бул свидоми о литературних конвенцийох творох хтори читал. Гуторел же найволєл читац тих писательох хторих могол розумиц и хтори му були блїзки по животним и литературним искустве. Василь Стефаник єден з тих писательох хтори значно уплївовали на литературне дїло Михайла Ковача, а у тей роботи ше анализує праве його уплїв на прозу Михайла Ковача. Простор валала, селянска душа и чежки живот селянох гевто цо найбаржей повязує дїло тих двох писательох.

Ключни слова: Василь Стефаник, Михайло Ковач, валал, жем, селянє.

На Михайла Ковача значно уплївовали класики українскей литератури. Ковач читал дїла велїх авторох, гоч нє вше бул теорийно свидоми о литературних конвенцийох творох хтори пречитал. Гуторел же найволєл читац тих авторох хторих могол розумиц и почувствовац, и тих хтори му були блїзки по животним и литературним искустве. Вон предлужує традицию українских писательох, алє $є$ нє писатель епигон, бо шицко цо превжал од других писательох присподобел так же би го Руснаци на долнєй жеми могли розумиц. То значи же мотиви и теми хтори обрабял у своїх дїлох, а на хтори уплївовали други писателє, прилагодзел гу животному искуству своїм сонароднїком на тих просторох.

Василь Семенович Стефаник українски писатель револуцийно-демократичного напряму, єден з найвизначнєйших писательох социялно-психологичней новели у дореволуцийней українскей литератури. Вон єден з україн-

* Статя фазни резултат роботи на проєкту „Дискурси мањинских језика, књижевности и култура у југоисточној и средњој Европи“ ч. 178017, котри финансийно потримує Министерство просвити, науки и технологийного розвою Републики Сербиї. 
ских писательох хтори значно уплївовали на Михайла Ковача. Стефаник ше народзел 14. мая 1871. року у Русове, у України. Школовал ше у родним месце, потим у Снятини. Одмалючка чувствовал же учителє и пански дзеци вишмейовали и понїжовали селянски дзеци, та и то вироятно познєйше уплївовало на його твори. По законченю основней школи уписал ше до польскей гимназиї у Коломиї. Як гимназиялєц почал читац уметнїцку литературу, твори Тараса Шевченка, Панаса Мирного, Марка Вовчка, Юрия Федьковича, Николая Чернишевского, Николая Нєкрасова, Глєба Успенского. Уж теди почал писац свойо перши твори. Тиж так, теди ше упознал 303 социялистичну литературу и дїлами Маркса и Енгелса.

Як школяр Коломийскей гимназиї, Стефаник вєдно з другима заинтересованима и обдарованима школярами, организує таємни кружок. Спочатку ше члени кружка занїмали зоз самообразованьом, а познєйше почали виступац з рефератами у читальньох, а тиж так и организовац нови читальнї. Пре таку дїялносц, Стефаника вєдно $з$ другима школярами, виключую з Коломийскей гимназиї. После того Стефаникови ше, вєдно з його товаришом, будуцим писательом Мартовичом, удало уписац ше до седмей класи Дрогобицкей гимназиї. Ту ше вон озбильнсйше упознава зоз социялистичнима идеями (Рамач/Чакан, 1973: 188).

Перши новели Василя Стефаника друковани у новинох Праия (1897), а два роки потим виходзи му перша збирка новелох Белава кнїжочка. Нсодлуга у Львове виходза ище його два збирки новелох Камени криж (1900) и Драїа (1901). 1905. року у Львове виходзи штварта збирка Стефаникових новелох под назву Мойо слово, а у Петербургу перше подполне виданє шицких його творох (на українским язику) з назву Прийовеgки. Його новели ше прекладаю и на польски, чески, французки, нємецки и други язики.

Стефаник активно участвовал у дружтвеним живоце, заступал селянох у судзе, порцийних управох. Прето єден час менєй писал, та ше аж 1916. року зявюю його новели Дзецинска йравgа и Мария, котри указую барз чежки стан народу под час першей шветовей войни.

Стефаник ше 1936. року чежко похорел, а 7. децембра истого року, у 65. року живота, умар.

Уж у перших новелох Стефаник ше указал як вельки майстор художного слова, талантовани писатель реалист; указал ше як новатор у способе ошветльованя чежких обставинох заходноукраїнского селянства (исте: 189).

Максим Горки гварел же Стефаник писал „кратко, силно и страшно”. Вон у кратких новелох знал виповесц вельки животни правди.

„... Ковач зоз своїм поетским реализмом по поетики найблїзши українским новелистом з початку XX вику, менєй Франкови а вецей Васильови 
Стефаникови (и тота релация вимага окремну поровнуюцу студию).’(Тамаш, 2009, 76).

У тей роботи представим єдну часц Стефаникового уплїву на Ковача. Понеже нєт студия о релациї тих двох писательох, окрем напрямкох у кнїжки Єваніеелистиа Михайло Ковач Юлияна Тамаша, як основу за дальше виглєдованє сом хасновала и Читианку за ІІІ класу гимназиї Юлияна Рамача, Мариї и Евгения Чакана. Окрем жридлових Стефаникових новелох на українским язику, хасновала сом и кнїжку Вибрани ирийовеgки Василя Стефаника (Васиљ Сиеефаник, Изабране йриче). До нєй позберани трицец шейсц Стефаниково новели хтори Стеван Константинович преложел на сербски язик.

Швет у Стефаникових приповедкох то швет валала, а так и у Ковачових приповедкох. До того швета уткани трагични судьби селянох, їх вязаносц за жем и родне место, чежки живот, часто то и борба за лєпши живот, алє и нєрозуменє оцох и дзецох. Шицко тото одредзело Ковача як приповедача, на тим ше фундаментує велька часц його поетики и тематика хтору обрабял у своїх приповедкох.

Новела Камени криж барз важна за поцагованє паралели и толковане уплїву Стефаника на Ковача. На основи тей новели мож указац же праве Василь Стефаник значно одредзел Ковача як писателя.

Главна подоба у новели Камени криж Иван Дїдух, старик, селян хтори барз вязани за жем и валал у хторим $є$ народзени. Ма свою жем, свойо польо на верх брега, та вєдно з коньом кажди дзень цага коч на тот брег. Од цаганя $є$ преламани у боку, ходзи схилєни, а на драги по верх брега случує ше же му ше церень задзеє до талпи. Вон нє винїма церень, церпи го и идзе далєй гу верху, на свойо польо, свою жем. Интересантне толкованє поняца церень: „1. Церень упутює на поняце препреченя, чежкосци и вонкашнсй одбрани, та на основи того на мучни и нєлагодни приступ. 2. У семитских и християнских преданьох церень упутює на нєобробену дзиву жем, та ше ю прето означує як церньовиту жем.”(Gerbran/Ševalije, 2013: 989).

Иван Дїдух обрабя жем хтору нїхто скорей нього нє обрабял. То барз чежка и вичерпююца робота, алє вон витирвали, бо $є$ барз вязани за тоту жем на хторей жиє одмалючка. Иваново синове и жена сцу пойсц жиц до Канади, думаю же там найду лєпши живот и щесце. А Иванови без огляду на тото же му ту чежки живот, ту його простор щесца, ту є медзи своїма и на своїм. Ясно видно же ше оцец и синове нє розумя, алє оцец попущує, та и вон пойдзе до Канади. За ньго то нє одход до лєпшого живота, алє нєизвесносц, а за душу шмерц. Прето себе и поставел камени криж на своїм полю на верх брега, як символ же з одходом до нєпознатого - умера. У тей новели приказани барз вельки животни правди: чежке положенє селяна, параста хтори муши барз вельо робиц, цали живот му барз чежки. Приказана вяза- 
носц селяна за жем хтору обрабя и на хторей жиє и символичне умеранє пре одход до Канади. Тиж так, приказане и нєскладанє родичох, точнєйше оцох и дзецох. Вше присутне нєрозуменє и нескладанє медзи людзми розличних генерацийох, а ту воно виволане пре иншаке дожице простора щесца. За оцох то родне место, їх жем, а за синох то нєпознати и далєки швет.

Подоби у новели нє маю интелектуализовани нукашнї швет. Вони обични, єдноставни селянє. Нє маю глїбшу психологийну мотивацию, алє ше индивидуализую по судьби, у одлучуюцих хвилькох у живоце и по способу живота. Репрезенти су шицких селянох, таких Дїдухох було вельо у тот час. На тот способ и Ковач будує подоби у своїх приповедкох.

Мож заключиц же Ковачово повойново приповедки настали на основи новели Камени криж. Ковачово повойново приповедки мож подзелїц на два круги приповедкох: о чловековей борби за лєпши живот и о зраженю „оцох и дзецох". Приповедки хтори до центру уваги кладу чловекову борбу за лєпши живот, а у хторих ясно видно вязаносц параста, Руснака, за жем на хторей є народзени то Вона єgина и Ляgова хмара.

Приповедка Вона єgина настала под директним уплївом Стефаниковей приповедки Камени криж. Главна подоба Яков Стокласка, селян зоз Руского Керестура. Пре чежки живот и туньшу жем у Славониї, муши ше 3 фамелию одселїц там, до цудзого краю. Цудзи край за шицких Руснацох хтори ше селя зоз места у хторим ше народзели до даєдного другого места дзе нєт Руснацох, та тото место, т. є. валал, нє чувствую як свойо. Потресна слика його одпитованя од жеми, дзе видно же ше у тей хвильки скаржи и предруцує єй: „О, кельо ши нас намножела и йозбивала на іромаgу, а теиераз нє маш кажgому gаи - єси... Нацо ши нас намножела кеg нас кармии нє можеш?" Гнїва ше на жем и гвари: „Жем чує, вона маи. Вона нам шицким мац.” 3 нього заш лєм вибива любов гу тей жеми: „бо вона маи наша, нє може без нас. Зажаяа ше нас, збера заш ту себе, врачаме ше оgкаgз зме иришли". У Яковови помишани чувства, но, любов гу жеми моцнсйша, а гнїванє на ню хвилькове. Муши ю охабиц пре єй терашню нєплодносц. Гнїва ше, бо муши пойсц: „Я би ииак любел нє иси далєко о м месйа gзе сом збачел иериу хмарку на нєбе." Одпитал ше од жеми, та рушел зоз жену и троїма дзецми до Славониї. Яков през драгу дума на будучносц, на тото цо там купели, а Маря, його жена, на прешлосц и гевто цо мали. Нову хижу ушорели як гевту у родним месце же би и ту мали руску хижу. Яков носталгию од себе дрилял так же вельо робел, та нє мал часу жаловац, а Маря була нєщешлїва. Но, гоч вельо робел, заш лєм мож обачиц пременку у Якововим справованю: „Лєм на йольо кеg виходзел - як gа ше менял. Хоgзел йо нїм як йо церкви, цихо, иомали, ровномирно. На нїм - зачуgо - нє йонайлял, нї̆gа..." 3 того видно яке Яковово одношенє гу новей жеми. Кед по новей жеми ходзел 
як у церкви, значи же бул стримани, алє же почитовал жем. И Яковови и Марї у цудзим валалє дом лєм у обисцу, у їх рускей хижи, а уж кед кроча на улїцу, нє чувствую ше як на своїм. Гоч жем першей єшенї добре родзела, случело ше им нєщесце з наймладшим дзецком. Похорело ше и умарло. Марї 3 тим подполно одвжате щесце и так гутори Яковови: „Поля ции gаю йлоg, буgзеш газgа, а йвой власни йлоg...Вон изи оgйаgнє єgен йо єgен. Мирончок йочал... а вец може и Дюри и Иринка. А веи йойgзем за нїма и я, а йи шеgз на нєй, тазgуй!" Маря з тим гутори же ше нє требало селїц до цудзого краю, бо ту шицки поумераю од жалю. Марю за нови край вяже лєм синов гроб, а цошка єй гуторело: „Нє жалоси ше, мила, нє жалосц...Виязиш, виаgзи вона, мач наша еgина."

Стефаник у своїх новелох представя лєм одредзени, ключни односно одлучуюци хвильки у людских животох, а охабя же би читаче додумали цо ше после тих хвилькох збуло. Так написана и новела Камени криж дзе приказана вязаносц за жем, одпитованє од валалчанох и од нєй, як и символичне хованє. Нє знаме цо ше случело по одходу до цудзей жеми и яки живот там дочекал Ивана Дїдуха и його фамелию. Вязаносц за жем Стефаник представел реално, без скриваня правди о чежкей и вичерпююцей роботи на полю. Дїдуха робота на полю вичерпала, польо го преламало, та ходзи схилєни, рано му чежко стануц пре його витрапени косци, алє шицко тото церпи, бо любов гу жеми моцнєйша од того церпеня. Вон тиж, як и Яков, свидоми же тота жем нє може накармиц телїх людзох. Обидвоме шицко попредали же би оможлївели одход за лєпшим животом до цудзого краю. 3 уж наведзених прикладох Яковового одпитованя од жеми, видно же тот момент и вязаносц за жем Ковач приказал вельо емотивнєйше. Стефаник нє таки емотивни, вон вше читачом сообщує правду таку яка $\epsilon$, та гоч $є$, а така $\epsilon$ найчастейше, барз сурова.

Дїдухово одпитованє од жеми представя 303 символичним каменим крижом хтори Дїдух поставя себе и своєй жени. Мена синох Дїдух нє написал на тот памятнїк, бо тота жем уж нє будзе їх. Стефаников старик зоз одходом символично умера. Ту ше новела и закончує, як кед би живота по одходу анї нє було.

Крижик присутни и у Ковачовей приповедки Вона єguна, такой першей єшенї кед Яковови и Марї умар син. Вон єдине од їх троїх дзецох хторе на одходзе з родного краю плакало, а у новим краю го пошвидко дочекала шмерц. Яков направел крижик синови. При Ковачови ше шмерц дословно случує, нє лєм символично. Маря осудзує мужа за шмерц сина, а Дюри роздумує о шмерци свойого брацика: „А за Мирончом му нє мало изо буц

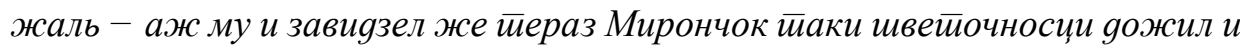

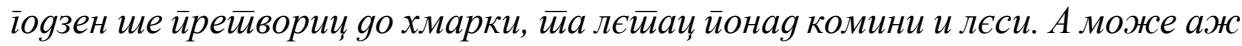


и йонаg бабову хижу у Керестиуре іоозен лєйаи." У тим роздумованю символика, бо хмари вше представяю Божу присутносц, а у Дюриковим споминаню Керестура $з$ хторого пошли, видно же памета гевтот стари край.

Яков у новим краю почина роздумовац о тим же би було крашнє кед би ше даєдни керестурски фамелиї преселєли до того валалу гу нїм, та би и свою церквочку могли подзвигнуц. Ту з нього виходзи гевто християнске, а обичайна вира характеристична за велї Ковачово, як и Стефаниково подоби. Дїдух, понеже предал шицку жем, бої ше же го Бог будзе осудзовац прето. Вон вери до Бога, алє до церкви ходзи раз рочнє. Но, же є християн видно и по тим же себе поставел криж, а на одходзе гварел приятельом же док умре, най даю на парастос. Яковова вира виходзи з нього аж после одредзеного часу препровадзеного у цудзини, кед роздумує о тим же би могли подзвигнуц свою церкву.

Дїдух и Стокласка представнїки селянох, то могол буц и гоч хтори други параст хтори пре чежки живот мушел шицко попредац и пойсц глєдац щесце у цудзини. То представя репрезентативносц характерох, цо єдно 303 седем началох Ковачовей историйней поетики.

Приповедка у хторей представена моцна вяза Руснака за жем то Ляgова хмара. Главна подоба у тей приповедки Янко Ходак, худобни селян, однєдавна оженєти з Ганю. Янкова вязаносц за жем директно представена у його

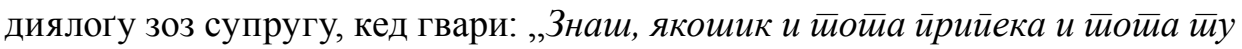

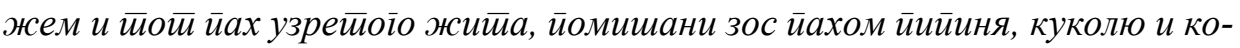

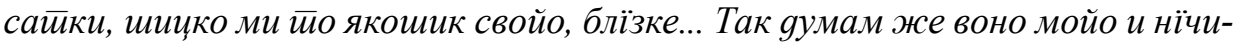
йо вецей, же розлука з тиим шицким тио би була истиочасно и моя шмери." Гоч яки му живот чежки, вон нє одустава од своєй жеми, та анї теди кед му ше указала нагода робиц за другого и заробиц вецей и гвари же слуга нє сце буц: „Там ирреба кажgи gзень буц акурайни, йам ирреба душу свою ирреgаи, иам ииреба буи йоіубени чловек кеg сиеш же би ши менєй робел, а вецей зарабял." При Стефаникови Свреє и Поляци вихасновюю селянох, а при Ковачови Мадяре. Анї єден анї други писатель ше нє бори процив того и нє намага ше пременїц таки стан, алє у тей приповедки на месце дзе спомина мадярски уплїв, видно же сце змоцнїц националну свидомосц при читачох. То хвилька кед Ковач бешедує з Янкових устох: „Там тиреба ирреgач мено и виру и чловечноси, знаш? Я би мушел буи Янош и нс Янко.” Од оца Янко достал жем и винїцу, алє нє на таким добрим месце на яким поля маєтнєйших валалчанох. Тот факт мож поровнац зоз местом на хторим ше находзи Дїдухово польо, бо воно на найгоршим месце коло валала, на верх брега. Прето жито на польох худобних познєйше дозревало. Богатши уж покошели свойо жито, а тоти худобнєйши ище нє, та ше уж бали од каменцу хтори би, кед би пришол, знїщел їх труд. През описованє места на хторим ше на- 
ходза поля богатих и худобних, приказани и социялни стан, односно же обични селянє на нїзшим положеню у одношеню на богатих и прето ше зна случиц же худобнєйши настрадаю. Тото ше случує и Янкови, бо пришол каменєц и знїщел поля худобним. ,Збунєни ӣойайрунки, нєgойовеgзени сло-

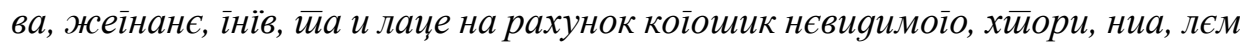
цуо нє висийал на нїх свой жовч, були єgине иррочивстиавянє йому цуо ше зос

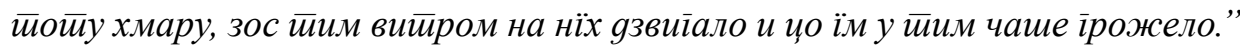
Янков гнїв представя гнїв шицких валачанох: „Уж ме забило! Виязиш тиам іевйо йасмо як ше сйущело? Воно ме забило!” Гнїва ше и лає Бога, гевто цо нє може видзиц, а цо йому и другим парастом знїщело роботу и на одредзени способ загрожело егзистенцию: „Вжал ши og іевйих цуо нє маю и gал

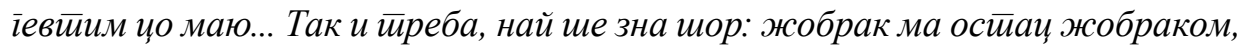
а газда газдом."

Стефаник, як уж спомнуте, у своїх новелох дава одлучуюци хвильки у живоце, алє нє и гевто цо ше по їх одвиваню случує. Ковач дава и одлучуюци хвильки, алє и голєм єдну часц гевтого цо ше потим случело. Так и у приповедки Ляgова хмара. То мож указац на прикладу Ганьового роздумованя о старим краю: „Вона знала лєм єgно: же би єй було красше жии у

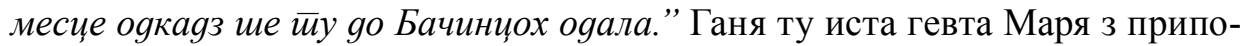
ведки Вона єguна, обидва нє можу прилапиц же вецей нє жию у родним месце. Обидва ше спокойно чувствую лєм дома, по хвильку док нє виду $з$ обисца. Ганя лєм у посцелї з Янком чувствовала мир.

Приповедки Вона єguна и Ляgова хмара настали под директним уплївом Стефаниковей новели Камени криж. У першей ту спомнутей Ковачовей приповедки присутни так повесц шицки мотиви хтори и Стефаник обробел: вязаносц за жем, борба за лєпши живот и одход до цудзого краю, з тим же у Стефаниковей новели нє познате яки живот после одходу, а Ковач и тото обробел. У другей приповедки присутни лєм мотив вязаносци за жем, цо нє значи же вона ма меншу уметнїцку вредносц. Любов гу жеми моцнєйша од гнїву и скарженя на природу.

Зраженє оцох и синох присутне у Стефаниковим Каменим крижу. Представене є як зраженє интересох двох генерацийох, оца хтори вязани за жем на хторей жил од народзеня и сином хторим ше видзи же лєпши живот пренайду у цудзей жеми. У новели ше директне зраженє нє случує, оцови важнєйше жаданє синох як його власне, гоч себе символично похова поставяюци камени криж на свойо польо.

У повойнових Ковачових приповедкох и круг приповедкох о зраженю „оцох и дзецох”. У Стефаниковей новели Камени криж присутне нєскладанє медзи оцом и синами, зражени їх интереси. Оцова любов пристала гу сином, та цала фамелия пошла до цудзей жеми. Оцец себе символично поховал пре 
любов гу сином. Понеже Ковача интересує и цо ше збува после одлучуюцих хвилькох у живоце, вон як кед би додумал цо ше случело по одходу до Канади и яки живот их чекал у цудзини. Зраженє оцох и дзецох ше у Ковачових приповедкох случує уж кед одлучуюци хвильки закончени, та мож видзиц їх пошлїдки. Зраженє медзи нїма настава пре генерацийни розлики, иншаке похопенє швета, алє и гевто цо Ковачови найчежше прилапиц - слабше чувство припадносци дзецох гу свойому народу, жеми, односно месту дзе су народзени, а вєдно з тим и гу традициї и култури. Так при Дїдухових синох, так и у Ковачових приповедкох о зраженю „оцох и дзецох”. У одношеню на Стефаника, Ковач розробел и причини за одлуки дзецох и указал пошлїдки тих причинох. На таки способ дал рижни можлїви вариянти. Єст вецей приповедки у хторих Ковач обробел тоту тематику, а за поровнованє сом видвоєла шлїдуюци: Розходзеня, Миколов швешиочни gзень, Празне їнїзgо и Добри животи. Тим приповедком заєднїцке же дзеци нє мали чувство припадносци гу народу и жеми на хторей ше народзели, а вибрали себе пари хтори нє по дзеки їх оцом и то причина пре хтору ше зражую. Дзеци нє вше мушели пойсц до цудзого краю, досц було же вибрали пару цудзей вири, та уж тото була основа за нєпорозуменє медзи генерациями.

У приповедки Розходзеня деда Мишка ше зоз сином зражує пре два причини, прето же син Янко нє сце обрабяц жем, и пре нєвесту. Оцец гвари: „Так ичи и ииреба, gураку, кеg ши дозволел синови стиаваи за робойнїка на шитерки, а нє же би ше жеми итримал." Син нє ценї оцову жем и видзи ше му же годзен вецей заробиц кед будзе роботнїк. Оцец нєзадовольни и пре жену яку себе вибрал Янко. Нє досц му тото, алє ше му и дзивка одселєла до цудзого швета до Славониї, , а йори йу Янко ирривеgол йлачлїву Илю gо обисиа, себе на карк, а йому, Михалови, на иеерху”. Пре нєвесту ше, обидвоме пияни, барз повадзели. Тота звада була одлучуюца. Янко после нєй знал же преда жем и пойдзе до Америки на єден час, а жени будзе посилац пенєж. 3 чином предаваня жеми указане нєпочитованє оцовей роботи з хтору обезпечел тоту жем.

Символичне Михалово припатранє на диждж и воду хтора чече, прелїва ше прейг ярчку и чече далєй. Вода нєше денечко хторе вон вистругал ище док му жена була жива. Хасновали го вельо роки, а нєвеста кед пришла, вируцела го и тераз го вода нєше з обисца: „...gatgзе зайнє, хйа ше ту краю, як кеg би ше оgнїмало. Та оgнїмане не йомаїа."

Тото денечко символизує старих, оца и мацер, а нєвеста го вируцела и 303 тим символично указане же праве з тоту нєвесту обисце вецей нє гевто цо було пред єй приходом. За тим стої синова одлука же ю вежнє себе за жену. Тиж так, з тим приказане и же младосц надвладала старосц, же будзе так як млади сцу, а нє як родичи думаю же би за нїх було найлєпше. Так и 
було, Янко одлучел пойсц до Америки и там и остал. Иля остала сама 303 сином хтори нїгда нє упознал свойого оца. Михал пошол жиц гу дзивки до Славониї, а там ше „gзеци йокус шмеяли зоз gїgовоїо мойаня на иуgзим язику." То шведоченє щезованя єдней фамелиї, язика и народа.

У приповедки Миколов швейочни gзень ше оцец, Микола, зражує зоз дзивку пре єй мужа, односно свойого жеца. Приповедка почина 3 описом звичайней нєдзелї у каждим руским газдовским обисцу. Хлопи попивкую палєнку, розпатраю цо у обисцу поробене през тидзень, жени варя, даваю хлопом дробни динари до дзвончка и хлопи одходза до церкви.

„Так робел Миколов оцец, ииак и Микола робел док бул, як ше ївари, у моци, gок бул вон тазда у обисиу. А як сииара ояумарла, а вон gзивки иоииристиановял, йо иалком иншак." 3 того видно же його дзивки не почитую обичаї своїх родичох и же Микола вецей нє газда у своїм обисцу. Тота нєдзеля иншака. Микола розчаровани же му жец Серб хтори, як ше йому видзи, лєм патри же би цо лепше єдол, а цо менсй робел. Кед би шицко було так як вон думал же будзе, кед би ше му дзивка одала за Руснака, тераз би ше рихтали до Шиду на Кирбай, а так Микола сам у пиньвици шедзи, пиє и мучи ше. „Вон уж ялуіи час анї з друіима не ирийовеgа лєм зоз собу. Ба, не лєм зос собу. Бешеgує ище зоз краву и зос йаркастиим стиарим Бундашом.” Животинї Миколови тераз векши приятелє як власна дзивка цо жиє з мужом ту, у його обисцу. Псови бешедує о шицких своїх бригох и о здогадованю на родичох. Памета як му мац гуторела: „... Ви ше, gзивчайа, нїяк нє оgавайце за Шокиох, іоч буgзеце шиви йлєси, а иии, Миколо, кеg ше нє оженїи з Рускиню, йа це иреклєєм - у іробе ше обрацим и - иреклєєм!” Миколу болї же його дзивка нє одата за Руснака, алє тот боль уж преходзи до гнїву, та гутори псови: „Tu

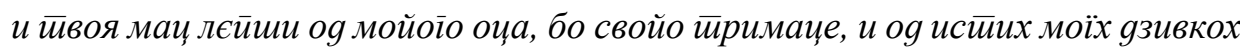
сце лєйши, бо знаще изо сие. " У тим монологу, гоч за ньго то диялог, бо бешедує зоз псом, Микола виповедол вельки боль. Вон чувствує же його дзивка нє ценї анї свой народ, анї його, свойого оца. На одредзени способ вон ю тераз нєнавидзи и прето осудзує аж и себе, бо, прави християн нє осудзує и не мержи других: „Но я gакеgи бул християн, бул чловек, як ше івари, а

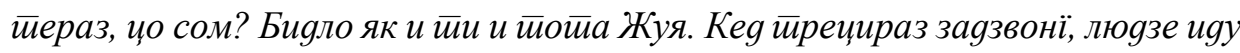
gо церкви, а ми йу на йажици йашеме..вилєіууєме ше, йоносуєме ше єgно gруіому..."

Микола практично вигнати з обисца. Там госцина, а дзивка ше за ньго ганьби, та му нє да же би бул медзи госцами. Вон то так доживює: ,...Мести $a$ у обисиу нє мам. Нєшка шветео, а я на ярку шеgзим и зос йсами бешеgуєм" Микола, тераз уж одшмелєни од палєнки, одлучел же пойдзе дому на госцину, а кед з псом и краву дошол гу капурки: 
Пес нє гварел нїч, алє гварела його дзивка Веруна кед му отверала капурку же би крава вошла: „Госии. Якишик йанове з Бачкей...A ви - же бисие ше тиам нє хйали ту нам gо хижи. Не сием же би вас виязели йакойо як жобрака, оброснуйоїо, у і анярох!" Нєпочитованє Веруни гу оцови окреме указане у хвильки у хторей ше гутори же вона отворела капурку крави, а нє оцови. Вона $з$ тим указала нє лєм же ше ганьби за оца, алє же го на одредзени способ и нєнавидзи: „Прешол тио, айо, час кеg ше я вас бала и кеg сом вас слухала, а иеераз маце ви мнє слухаи.” Таке Верунково справованє го ище баржей розгнївало, та на силу вошол до обисца, чувствовал ше як жобрак кед жобра, а нїч нє достанє и ище го людзе и одплаша од себе. Миколов єдини приятель остал пес Бундаш. През його споведанє псови, зваду зоз дзивку и жецом и хвильку кед го вони вигнали з обисца приказане його церпенє и вельки боль у души. Найчежша хвилька то зраженє з дзивку хторе приказанє на брутални способ, писатель сцел цо виродостойнєйше тото приказац. Дзивка зрадзела оца, а младосц заш надвладала старосц хтора остала сама, уквилєна и у болю. За Стефаниково подоби характеристичне же його подоби часто церпя, маю вельки бриги у живоце. То найчастейше пре войну и худобство хторе загрожує їх егзистенцию. Ковач нє идзе по тоту крайносц же його подоби на гранїци егзистенциї, алє його подоби часто, праве як и у тей приповедки, церпя пре уквильованє своїх дзецох и боль настава пре зраженє з нїма.

У приповедки Празне їнїзgо нє случує ше директне зраженє медзи оцом и дзецми, алє одлуки дзецох же буду жиц у цудзим краю, у оцови виволую церпенє, боль и смуток.

Дїдо Денчи Дротар остал гдовец, син му умар, а дзивки ше попристановяли и жию у Славониї. Вон ше знова оженєл, алє є нєщешлїви. Чежко му було пойсц зоз свойого обисца до обисца другей жени. Там чувствує самоту. 3 тим тиж указана вязаносц чловека за свойо, за место дзе препровадзел найвецей роки свойого живота и гоч ше обставини пременя, чежко ше звикнуц на цалком нове.

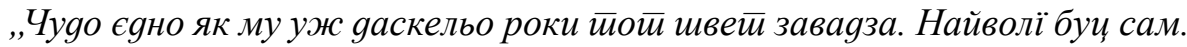
Смуйно му самому, а заш лем найволї буи сам зоз свойм смуйком.” Не жиє вецей нї зоз ким од наймилших и найблїзших, а гоч ше и оженєл, осамени є. Гвари же то нє весели и складни мир у обисцу, алє же тот мир смутни, бо кажде у своїх думкох. Пре тоту осаменосц дїдо Денчи вельо роздумує, а найвецей о дзецох. Велька символика у празним гнїзду ластовки на хторе ше припатра. Тото гнїздо вон поровнує зоз власну судьбу. Дїдо так роздумує: „Дзеци виросли, gостиали крияла и - іуя, вецей враианя gо стиароїо їнїзяа

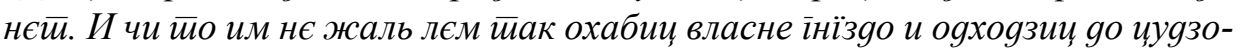
іо шветиа?" Чежко му же є сам, чувствує ше як кед би бул мертви пре тоту 
осаменосц. 3 того видно и дїдову вязаносц за родни край и жаль же дзеци то нє так чувствую як свойо. То причина його церпеня.

Стефаниково подоби ше часто зочую зоз шмерцу - або ю доволую, або им дахто зоз фамелиї умера. То нє таки части мотив при Ковачови, алє у тей приповедки ше зявює. Дїдо Дротар ше бої од шмерци, „бо кеg вон завре очи, нїхтио о нїм gзень - gва анї нє gихнє”.' Бої ше же шицки по його шмерци забуду на ньго, а роздумує и о тим цо би було кед би му син нє умар. Шмерц жени и дзецка тиж цошка прецо вон церпи. Бул чесни и шпоровни чловек, створел обисце, а вец як кед би му дзеци на тото шицко гварели же им його труд нє потребни. Так ше му видзело же дзеци вообще нє ценя гевто цо вон створел.

Женїдба по други раз и одход до нового обисца за ньго представя одход до цудзого краю и чежко му розисц ше зоз старим обисцом. У новим обисцу себе пошвидко справел труну и крижик. У тим исто символика. 3 одходом 303 свойого обисца бул вше блїжей при шмерци. Тиж так, барз го трапело же му дзивки поодавани у цудзини. Сдину радосц до живота му унєсла унука Павлинка кед пришла до ньго служиц. Дїдо одлучел же ше 303 ню враци до Славониї и же нагвари єй родичох най приду шицки вєдно до ньго жиц. Драга до цудзини го одведла просто до шмерци. Труна и крижик як кед би були перше нагадованє, символ шмерци, а драга до цудзини, драга на гевтот швет. Абсурд характеристични за Стефаниково твори, а абсурд ше у тей Ковачовей приповедки зявює праве на месце кед дїдо лєм цо нє сцигол гу своєй дзивки. Пред самим местом до хторого ишли, прегажел го гайзибан, а поховали го у цудзим месце, цудзей труни, на цудзим теметове. То наисце абсурд кед познати факт же себе сам справел труну и крижик же би бул поховани на теметове у месце у хторим жил. „Остиал у иуgзим швеце сам.'

У приповедки Празне їнїзяо мож препознац вельки Стефаников уплїв. Одход зоз свойого обисца, зочованє зоз шмерцу наймилших, зраженє з дзецми пре їх одход до цудзини, а хтори и оца тих дзецох одведол до шмерци. Ту и рихтанє труни и крижика пре одход зоз свойого обисца. Шицки тоти мотиви присутни и у Каменим крижу Василя Стефаника. А, насампредз, то щира и чесна душа селяна хтори церпи.

Ище єдна приповедка з кругу Ковачових приповедкох о зраженю „оцох и дзецох", а на хтору уплївовал Стефаник то Добри живой. У тей приповедки слово о фамелиї Михала Барни хтора ше преселєла до славонского валалу и там були єдина руска фамелия. 3 тоту приповедку Ковач як кед би додумал єдну верзию можлївого законченя спомнутей Стефаниковей новели. И ту присутни одход до цудзого краю хтори 303 собу ноши шмерц єдного члена фамелиї, дзецка. 
Дїя ше случує у чежким войновим чаше, шицки жию у страху, хлопи одходза до войска, а жени ше модля же би хлопи прежили. Старши син 3 Барновей фамелиї уж у войни. Младши, осемнацрочни Дюра ше „лаши” на тих цо одходза войовац. За ньго одход до войни доказ же є одроснути хлоп и причина пре хтору би други за нїм плакали, а то би ше му пачело. И вон би сцел войовац и буц герой. То абсурд, хтори, як сом спомла, нє таки части у Ковачових приповедкох, алє при Стефаникови абсурди части, та и тото уплївовало на Ковача.

Дюра ше сходзи з Кату, а любов гу нсй го аж и одбива од жажди за войну. Пре Кату ше зражує з оцом. Вона Горваткиня, а Дюров оцец би сцел мац нєвесту Рускиню. Двойо млади свидоми того, алє взаємна любов моцнєйша од чувства припадносци гу свойому народу. Оцец так дудрал на сина: „Тоти хлайеи ме gо іриху навеgзе - gуярал сииари - о розума ме одженє зос своїм сиравованьом. Местио же би иришол gому, вон заш йошол иростио ту своєй Шокици. Жиєме меgзи иудзим шветоом и gармо я іосиим и жандарох и новйаруша - удаю, иовеgза, дочекаю, забию, йа вец цо буgзе... Най забию, бийанtу - вирвало ше му наїлас - и йак з ньоїо нї̈gа чловек нє буgзе!” То тиж абсурд, Стефаников уплїв, а окреме у случаю дзе оцец жада свойому дзецку шмерц, бо то присутне при Стефаникови. Нє знал оцец же на концу так и будзе. Катов оцец тиж нє любел того хторого себе Ката вибрала за легиня. Анї Катов, анї Дюров оцец нє були задовольни з пару свойого дзецка. Обидвоме сцели же би пара бул дахто з їх власного народу, а нє було так. Любов младих була моцнєйша од їх почитованя оцових жаданьох, алє нє тирвала длуго. Пошвидко умарте лєжало у кукурици. Тото умарте бул Дюра. Миколови умар и други син. Чувствує Микола же то прето же вон надумал одселїц ше до цудзини. Свидоми $є$ же би його унучата у його обисцу вироятно бешедовали на цудзей бешеди. Док роздумує о тим, на хвильку му на розум приходзи и така думка: „Аж и gобре же Дюра вецей нє буgзе йому, Миколови, брити заgавач.” То абсурдна думка, єй абсурдносц ше звекшує и 303 тим же оцец пожадал синови шмерц, а кед син умар, у єдней хвильки то дожил як олєгчанє. При Стефаникови, як уж спомнуте, присутне жаданє шмерци себе, або своїм дзецом. Найекстремнєйша його приповедка на тоту тему то Новоси у хторей оцец сам реализовал тото жаданє. Остал гдовец, та младше свойо дзивче о єден час забил, а старше, свидомше, вимодлєло од нього живот. Стефаниково подоби жадаю шмерц и у шмерци видза векше щесце як у таким живоце у хторим нє маю цо єсц и егзистенция им загрожена.

Шмерц Миколового сина нє лєм шмерц сина, алє шмерц цалого його труду, капиталу, шицкого цо створел. Вон ше преселєл до цудзого краю же би себе и своєй фамелиї обезпечел лєпши условия и створел векши капитал, 
а тераз шицко тото нє ма кому дац. Миколова жена ше врацела до свойого

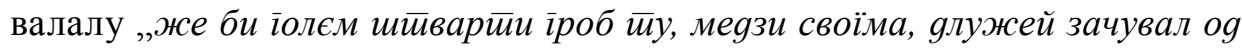
забуиа мено Барна Микола иоо охабел свойо їнїзяо и йошол gо швейа їлєgаи gобри живоши.” Ковач сцел указац же така судьба велїх фамелийох хтори ше преселя до цудзого краю. То нє муши буц буквалне умеранє членох фамелиї, алє гашенє членох народу з хторого пошли.

Стефаников Дїдух пошол до цудзого швета же би своїм сином обезпечел лєпши живот, а Ковач у тей приповедки дал єдну можлїву вариянту по одходу до цудзини. Єдна руска фамелия прето вимарла. Тот мотив мож повязац з ище єдним уплївом Стефаника на Ковача. То дружтвено-аналитична функция, народни препород и стабилизованє нациї. Тоту функцию двоме писателє витворюю на иншаки способи. При Стефаникови ношителє националного препороду млади школовани синове. Вони свидоми же су припаднїки українского народу, боря ше за Україну, а свидомосц о тим преноша на своїх родичох и других валалчанох. При Ковачови то иншак. Старши, родичи, баби и дїдове гевти хтори национално освидомени, а млади, їх дзеци, помали траца тоту свидомосц. Його подоби не гуторя: „Ми Руснаци”, алє вон дружтвено-аналитичну функцию иншак витворел.

У тей роботи представени даскельо Ковачово приповедки о зраженю „оцох и дзецох”. Зраженє ше у тих приповедкох случує прето же дзеци себе вибрали пари $з$ другого народу. Ковач указал цо ше можев случиц з такима малженствами дзе ше директно траци єдну вязу з родичами, бо дзеци тих младих, а родичово унуки, найчастейше нє знаю бешедовац по руски. 3 указованьом будучносци на таки способ пробовал у своїм народзе пребудзиц националну свидомосц.

На националну свидомосц и зраженє оцох и дзецох ше надовязує и опозиция предки/потомки и валал/варош.

У Стефаниковей приповедки млади порихтани попредац шицко цо родичи створели и пойсц жиц до цудзини. При Ковачови млади тиж одходза $30 з$ свойого краю. Оцом и у Стефаникових и у Ковачових приповедкох нєпохоплїва тота нєвязаносц за родни край и жем на хторей виросли. 3 того виходзи вичне Ковачово питанє: Чи йоиооки gосииойни своӥх йреgкох? Тиж так, и опозиция валал/варош присутна при обидвох писательох. Стари нє похопюю як млади можу жиц у варошу. То окреме обачлїве понеже подоби у їх приповедкох звичайно старши людзе хтори жию на валалє, та им живот у варошу дзе ше млади одходза школовац або жиц, далєки и страни.

Цо ше дотика Стефаникових и Ковачових подобох, то звичайно старши валалчанє, часто су покус чудни, алє то пре обставини у яких жию и ситуациї до хторих их живот кладзе. Специфична репрезентативносц подобох, бо тоти двоме писателє нє индивидуализую подоби. Иван Дїдух могол буц 
гоч хтори чловек з валалу хтори зочени з таку животну ситуацию, а тиж так, то ше одноши на було хторого старика зоз Ковачових приповедкох.

Звичайно вони шицки християнє, а християнство за нїх значи пойсц внєдзелю, або на вельки швета, окреме на Крачун и Вельку ноц, до церкви, поприберац ше до служби, здравкац „Слава Исусу Христу” и вериц же так ма буц, бо то Божа воля.

Понеже при обидвох писательох подоби найчастейше старики, часто присутне и їх дожице самоти. То окреме видно кед ше повяже два приповедки, Стефаникову Сама-самучка и Ковачову Боляци рани. У обидвох приповедкох главни подоби старши жени, баби. Обидва жию сами. Стефаник нє указує як баба церпи, вон лєм дал сличку баби нєпостредно пред шмерцу. У Боляциих ранох дата ширша сличка. Баба Ганя жиє сама, церпи. Жаль єй же дзивка пошла жиц до варошу и свидома є же єй дзивку нє интересує як єй мац. То єдна з ридких Ковачових приповедкох у хторих подоби доволую шмерц за себе. Баба Ганя гвари: „Боже, кельо же цуе раз буgзем модлїц же биш уж раз окончел зо мну? Кеg уж нє мам нїч на швеце, нач и мнє йу йримаш йельо?” Вона вецей раз гутори Богови же сце умрец. Цали вечар и цалу ноц ше трапи у бригох, та у нїх и умера. Умера сама, як и баба у Стефаниковей приповедки, з тим же Стефаник до своєй приповедки уткал и празновирє, хторе часте при валалских людзох. Бабу у його приповедки забили чорцики хтори вишли спод пеца. Интересантне же ше у обидвох приповедкох зявюю мухи, а вони символизую нєпреривне знємирйованє. 3 мухами повязане и празновирє. Ковач тото вихасновал, та празновирє представел 3 бабовим вереньом же велька муха праве єй дзивка Ката хтора лєм пришла видзиц кеди єй мац умре.

Празновирє при валалских людзох присутне у Стефаникових приповедкох, а присутне $є$ и при Ковачови, окреме у кругу фолклористичних медзивойнових приповедкох. Понеже його медзивойново приповедки забавного характеру, празновирє читачом представел на франтовлїви способ и вишмеял го. Хованєц єдна $з$ тих приповедкох. Бачи Янко пришол з Америки и мал вельо пенєжи. У валалє ше бешедовало же му тот пенєж дава чорцик цо го кура вилягла. Аж себе людзе надумали же пре того чорцика їх крава нє дава млєко, же им пре ньго швиня здохла. Юла прето сцела того чорцика забиц, а Яни бул порихтани на таке. Пошла до ньго и кед остала сама у хижи, пошла гу шкатулки за хтору думала же чорциков дом и отворела ю. Чорцик ше єй уцагнул до кошулї и нарабял, та ю аж и людзе почали ратовац. Кед го лапели, видзели же то обична миша. Так Ковач вишмеял празновирє при людзох.

Наймоцнєйши уплїв Стефаника на Ковача, представянє швета такого яки є. Стефаник так представя живот у своїх приповедкох, а Ковач на таки спо- 
соб гутори народу жє яки є, т. є. гутори народу правду и теди кед ю народ нє жада чуц. Тиж так, то и спомнути простор валала и селяна як главней подоби, його вяаносц за жем 3 хторей и на хторей жиє и чежке подношенє одходу до цудзого краю, алє кед жаданє його дзецох же би пробовали пренайсц лєпши живот дагдзе индзей, вон им тото жаданє сполнює, гоч себе сам символично похова. У Ковачових приповедкох хтори обрабяю тоту тему ше шмерц дословно случує, нє оцох, алє дзецох. 3 тим у вязи ище єден уплїв Стефаника, а то дружтвено-аналитична функция, як народни препород и стабилизованє нациї хторе Ковач у своїх дїлох окончує так же указує судьбу руских фамелийох хтори ше одселєли до цудзого краю, як и будучносци гевтих хтори себе за пару виберу припаднїка з другого народу.

\section{ЛИТЕРАТУРА}

Gerbran, A., Ševalije, Ž. (2013). Rečnik simbola: mitovi, snovi, običaji, postupci, oblici, likovi, boje, brojevi. Novi Sad: Stylos art - IK Kiša.

Рамач, Ю., Чакан, М., Чакан, Е. (1973). Читианка за III класу тимназиї. Нови Сад:

Покраїнски завод за видаванє учебнїкох.

Stefanik, V. (2001). Izabrane priče. Novi Sad: Knjižarska zadruga „Ljubitelji knjige”.

Тамаш, Ю. (1997). Истиория рускей лииеерайури. Београд: Завод за уџбенике и наставна средства.

Тамаш, Ю. (2009). Єваніеелисӣа Михайло Ковач:сӣуgия. Нови Сад: Руске слово.

Tamaš, J. (2002). Ukrajinska književnost između Istoka i Zapada. Novi Sad: NIU Ruske slovo-Prometej.

http://www.ukrcenter.com/Лiтература/ 
Ana Rimar

\section{THE INFLUENCE OF VASILJ STEFANIK ON MIHAJLO KOVAČ'S LITERARY WORKS}

\section{SUMMARY}

In this work we analyze the influence of Vasilj Stefanik on Mihajlo Kovač. These two writers are closely connected to each other by the village area and the descriptions of hard life of the peasants. The strongest influence of Vasilj Stefanik on Mihajlo Kovač is most obvious in presenting the world as it is. Stefanik depicts the life as it is in his stories, and Kovač openly tells the truth to the people even though they won't hear about it. The peasant is the main character as is his connection to the land from which and on which he lives. Connected to this is the social and analytical funtion as the national revival and the stabilizing of the nation.

Key words: Vasilj Stefanik, Mihajlo Kovač, village area, land, social and analitycal function. 